\title{
簡易宿泊所密集地区における福祉機能転用の実態と課題 THE CURRENT STATUS AND PROBLEMS OF CONVERSION INTO WELFARE FACILITY IN FLOPHOUSE AREAS
}

\author{
大野和彦*, 斎尾直子** \\ Kazuhiko ONO and Naoko SAIO
}

\begin{abstract}
Flophouse areas were formed by establishing many restaurants, amusement facilities and flophouses densely around employment agency for day laborers. The areas were once the base for day laborers. Recently, due to serious aging of long-term residents in the areas, some of snack bars and pachinko parlors converted into welfare facilities like day care centers for elderly. On the other hand, becoming welfare areas for low-income elderly is problem to be discussed.

This research aims to explore current status and problems involved in the conversion into welfare facilities in flophouse areas by analyzing secular changes of facility function and direction of support for long-term residents.
\end{abstract}

Keywords : Flophouse, Population aging, Conversion into welfare facility, Facility function, Secular change of facility 簡易宿泊所, 高齢化, 福祉転用, 施設機能, 施設経年変化

\section{1. 研究の背景と目的}

簡易宿泊所が密集した地区は一般にドヤ街と呼ばれ、簡易宿泊所 の周辺に飲食店や遊技施設が多く立地することで形成された。簡易 宿泊所は 3 畳程度の宿泊室から構成され、食堂やロビー等の共用空 間をもたず、設備はコインシャワー等のみ、宿泊費が 1500 円前後 の安宿であり、日雇労働者の生活拠点となってきた。しかし近年で は、かつての日雇労働者の高齢化に対応し、地区内のパチンコ屋や 居酒屋がデイサービスセンター等の福祉施設に転用寸る事例が多く みられる等、地区の様相は変容している。

簡易宿泊所宿泊者は、(1)かつての日雇労働者である高齢の宿泊 者・要介護者、(2)現役日雇労働者、低所得者や生活困穿者、(3)外国 人バックパッカー等の旅行者、と近年多様化している。そのうち、 (1)かつての日雇労働者である高齢の宿泊者・要介護者は、宿泊室で 住民票を取得しながら生活保護を受給し、健康状態に問題がある場 合は宿泊室で在宅介護を受ける等しながら、10 年以上地区で生活 を続ける宿泊者も多く、この状況は「居住」とみなすことができる。 本研究では主な地区住民である(1)かつての日雇労働者である高齢の 宿泊者・要介護者を「長期居住者」とし、分析対象とする。

本研究は、首都圈において代表的な簡易宿泊所密集地区である寿 地区・山谷地区を対象としている注1)。寿地区は神奈川県横浜市に 位置し、簡易宿泊所は中高層の RC 造が中心である ${ }^{11)}{ }^{-12)}$ 。山谷地区 は東京都台東区・荒川区にまたがって位置し、簡易宿泊所は老朽化
した低層の木造建築が中心である $\left.{ }^{20)}-22\right)$ 。両地区において、住宅地 図分析による機能の経年変化、及び現地調査による居住者支援の方 向性の考察を行ない、福祉機能転用の実態と課題を明らかにするこ とを目的とする。

関連する既往文献では、9）は訪問事業を中心とした介護・医療少ー ビスの実施等について言及している一方で、地区利用者層の中で主 に生活保護を受給していない生活困窮者やホームレスに着目してい る。また、10）-12）は簡易宿泊所密集地区における諸施設の居住 実態を扱っている。また、簡易宿泊所転用施設に関して、その成立 過程と転用による空間の変容から現状の計画課題を考察するものが みられる ${ }^{13)}$-19)。また、ホームレスの居住支援をおこなう簡易宿泊 所転用施設における生活実態を調查し野宿生活者への居住支援の可 能性を考察するものがある ${ }^{20)}$-22)。これらの既往文献は、1 施設内 での支援内容を調査したものが多く、地区内の複数の福祉施設を対 象としたものは少ない。また、地区内の施設の経年変化を追うこと で福祉機能の転用実態について論じている研究はなく、この点にお いて本研究は新規性があるものと考える。さらに、地区の機能が軒 並み福祉転用していく過程を把握しながら、狭域の街区に低所得の 高齢居住者のみが集まって長期的に生活し続けることの課題につい て考察することは重要である。

研究構成を Fig. 1 に示す。 2 章「長期居住者の高齢化に伴う簡易 宿泊所内での福祉サービス提供（survey1,2,3）」では、簡易宿泊所

* 国土交通省 修士 (工学)

** 東京工業大学環境 $\cdot$ 社会理工学院建築学系 准教授 $\cdot$ 博士 (工学)

Ministry of Land, Infrastructure, Transport, and Tourism, M.Eng.

Assoc. Prof., Dept. of Arcitecture and Building Engineering, School of

Environment and Society, Tokyo Institute of Technology, Dr.Eng. 
居住者の高齢化と長期居住実態、及び簡易宿泊所居住者への訪問福 祉サービス内容を把握する。3 章「1989 年以降における福祉施設の 経年変化（survey4）」では、1989 年から 2016 年までの福祉施設の 経年変化を分析し、健康な宿泊者が利用していた機能の福祉転用実 態を明らかにする。 4 章「長期居住者の生活空間課題と支援の方向 性（survey5, 6)」では、4-1 で簡易宿泊所の空間実測調查を行ない、 高齢の居住者が地区内に増加した福祉施設のサービスを利用しなが ら空間条件の厳しい簡易宿泊所に長期生活することの課題を考察し ている。また、4-2 では介護サービス事業所等を対象としたヒアリ ング調查により長期居住者への支援内容を把握し、地区内ニーズの 変化に伴う居住者支援や機能転用の方向性を考察する。

調查概要をTable1 に示す。 survey1 は各自治体福祉部局、及び 各地区での日雇労働を管理する労働福祉センターが発表している調 查資料 ${ }^{3)}$-6) を対象とし、survey2 は簡易宿泊所への訪問サービスを 行なう長期居住者支援組織・介護事業所の活動報告を対象とした文 献調査である。 survey3 は、養介護施設、保護施設における設備及 び運営に関する基準を規定する厚生労働省令 ${ }^{7)}$ を対象資料とした、 福祉機能の抽出に関する文献調查である。 survey4 は住宅地図調查 8) であり、1989 年から 2016 年までの施設経年分析を行なっている。 survey5 は、簡易宿泊所の実測調査、及び簡易宿泊所管理者へのヒ アリング調查（2016 年 9 月〜 12 月）であり、地区内の 4 簡易宿泊 所を宿泊して行なった。 survey6 は、各自治体福祉部局、長期居住 者支援 NPO 組織、介護サービス事業所を対象としたヒアリング調查 （2016 年 9 月〜 12 月）である。

2. 長期居住者の高齢化に伴う簡易宿泊所内での福祉サービス提供 2-1. 宿泊者の高齢化と居住の長期化

各自治体福祉部局、及び各地区での日雇労働を管理する労働福祉 センターが発表している調查資料 ${ }^{3)}{ }^{6)}$ について文献調查を行ない、 簡易宿泊所の宿泊者層を明らかにする。

Table2 は簡易宿泊所の宿泊者層を表したものである。両地区に おいて、1989 年前後にかけて日雇労働求人数は最大となっている。 バブル崩壊後、不況や労働の機械化・効率化が進む中で就労機会を 得ることができる労働者が激減し、現在地区で取り扱われる日雇 労働求人数はピーク時の $5 \%$ 程度となっている。また、地区が労働 市場としての機能を失いつつある中で、簡易宿泊所を住居として

生活保護を受給し、地区内に長期居住する高齢の居住者が増加し ている。山谷地区では 2015 年時点で、宿泊者の $79 \%$ が 60 歳以上、 $91 \%$ が簡易宿泊所を住居として生活保護を受給している。また、宿 泊者の $37 \%$ が地区に 10 年以上居住、さらに 60 歳以上の宿泊者の $44 \%$ が 10 年以上地区に居住しており、簡易宿泊所が宿泊施設の範 疇を超えた長期生活の場となっている状況が確認できる（Fig. 2)。

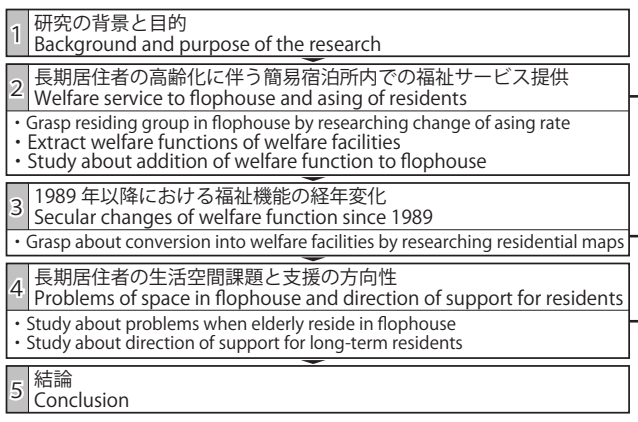

Fig. 1 Research method

Table 1 Survey overview

\begin{tabular}{|c|c|c|c|}
\hline No. & method & target & contents \\
\hline [1] & Literature survey & $\begin{array}{l}\text { References } 3 \text { () -6) announced by : } \\
\text { - each local goverment } \\
\text { - labor and welfare center }\end{array}$ & $\begin{array}{l}- \text { The number of labor offers } \\
\text { - aging rate } \\
\text { - public assitance recipient rate } \\
\text { years of residing }\end{array}$ \\
\hline [2] & Literature survey & $\begin{array}{l}\text { Activity reports of : } \\
\text { - care office } \\
\text { - support group for residents }\end{array}$ & $\begin{array}{l}\text { Details of visiting welfare } \\
\text { services to flophouse }\end{array}$ \\
\hline [3] & Literature survey & Ordinances for welfare facility & Details of welfare function \\
\hline [4] & $\begin{array}{l}\text { Secular analysis } \\
\text { by residential maps }\end{array}$ & \begin{tabular}{|l|} 
ZENRIN residential maps in : \\
- Naka-ku, Yokohama \\
- Taito-ku and Arakawa-ku, Tokyo \\
\end{tabular} & $\begin{array}{l}\text { Secular change of } \\
\text { welfare facilities }\end{array}$ \\
\hline [5] & $\begin{array}{l}\text { Measurement survey } \\
\text { by lodging flophouses }\end{array}$ & 4 flophouses in the areas & $\begin{array}{l}\text { - inner space of flophouse } \\
\text { - current status of management }\end{array}$ \\
\hline [6] & Hearing survey & $\begin{array}{l}\text { - local goverment } \\
\text { - support group for residents } \\
\text { - care office }\end{array}$ & $\begin{array}{l}\text { Direction of support for } \\
\text { long-term residents }\end{array}$ \\
\hline
\end{tabular}

Table 2 The change of residing group of flophouse

\begin{tabular}{|c|c|c|c|c|c|c|}
\hline & \multicolumn{2}{|c|}{$\begin{array}{c}\text { 日雇労働求人数 } \\
\text { The number offers }\end{array}$} & \multicolumn{2}{|c|}{$\begin{array}{l}60 \text { 歳以上人口割合 } \\
\text { Over the age of } 60 \text { rate }\end{array}$} & \multicolumn{2}{|c|}{$\begin{array}{c}\text { 生活保護受給人口割合 } \\
\text { Public assistance recipient rate }\end{array}$} \\
\hline & \begin{tabular}{|l|}
1989 \\
\end{tabular} & \begin{tabular}{|l|}
2015 \\
\end{tabular} & 1991 & 2015 & \begin{tabular}{|l|}
1991 \\
\end{tabular} & 2015 \\
\hline $\begin{array}{l}\begin{array}{l}\text { Kotobuki area } \\
\text { (Yokohama) }\end{array} \\
\end{array}$ & 154861 & $\begin{array}{c}8121 \\
\text { (4.1\% of the peak) } \\
\end{array}$ & $14.5 \%$ & $68.3 \%$ & $26.9 \%$ & $87.6 \%$ \\
\hline $\begin{array}{l}\text { Sanya area } \\
\text { (Tokyo) }\end{array}$ & 427152 & $\begin{array}{c}20400 \\
(4.8 \% \text { of the peak })\end{array}$ & $26.8 \%$ & $78.5 \%$ & $10.4 \%$ & $91.4 \%$ \\
\hline
\end{tabular}

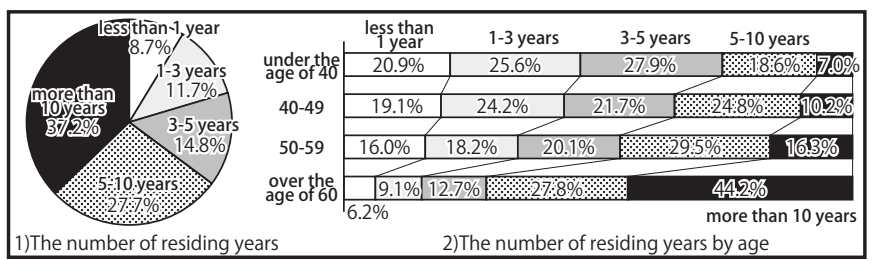

Fig. 2 The number of residing years in Sanya area in 2015

Table 3 Overview of welfare function

\begin{tabular}{|c|c|c|c|c|c|c|c|c|c|c|c|c|}
\hline welfare function & overview of welfare services & $\begin{array}{l}\text { 簡易宿泊所 } \\
\text { flophouse }\end{array}$ & \begin{tabular}{|l} 
高齩者 \\
house for \\
holderly
\end{tabular} & 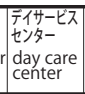 & $\begin{array}{l}\text { 養謢 } \\
\text { 老人ーム } \\
\text { care } \\
\text { facility }\end{array}$ & 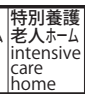 & $\begin{array}{l}\text { 軽费 } \\
\text { mod-ム } \\
\text { moderate- } \\
\text { fee home }\end{array}$ & 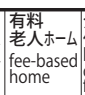 & 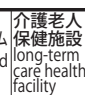 & $\begin{array}{l}\text { 救護施設 } \\
\text { relief } \\
\text { facility }\end{array}$ & $\begin{array}{l}\text { 更生施設 } \\
\text { rehabili- } \\
\text { tation } \\
\text { facility }\end{array}$ & 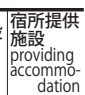 \\
\hline $\begin{array}{l}\text { 〈宿所の提供〉 } \\
\text { Providing Accommodation }\end{array}$ & - Having bedroom or living room for elder people, needy people & & & & & & & & & & & \\
\hline $\begin{array}{l}\text { 作業指導〉 } \\
\text { Work Instruction }\end{array}$ & $\begin{array}{l}\text { - Instruction for independence through working program } \\
\text { - Welfare program for recovery of alcohol or drug dependence, sickness }\end{array}$ & & & & & & & & & & & \\
\hline $\begin{array}{l}\text { 〈自立支援〉 } \\
\text { Independence Support }\end{array}$ & $\begin{array}{l}\text { - Necessary support for social life, Transition support for employment } \\
\text { - Prosedural support for daily life to administrative agency }\end{array}$ & & & & & & & & & & & \\
\hline $\begin{array}{l}\text { 〈趣味活動の場〉 } \\
\text { Place for Activity }\end{array}$ & $\begin{array}{l}\text { - Recreation activity } \\
\text { - Providing opportunity for activity about tastes, hobby, culture } \\
\end{array}$ & & & & & & & & & & & \\
\hline $\begin{array}{l}\text { 〈食事の提供〉 } \\
\text { Food Supply }\end{array}$ & - Supplying food at the right time & & & & & & & & & & & \\
\hline $\begin{array}{l}\text { 入浴機会の提供〉 } \\
\text { Opportunity to Bathe }\end{array}$ & - Providing opportunity for taking a bath, wiping body & & & & & & & & & & & \\
\hline $\begin{array}{l}\text { 生活支援〉 } \\
\text { Living Support }\end{array}$ & $\begin{array}{l}\text { - Advice and support about daily life, Safety check by watching round } \\
\text { - Management of money, taking medicine }\end{array}$ & & & & & & & & & & & \\
\hline $\begin{array}{l}\text { 〈健康管理〉 } \\
\text { Health Management }\end{array}$ & - Physical checkup, Health-condition management & & & & & & & & & & & \\
\hline $\begin{array}{l}\text { 機能訓練〉 } \\
\text { Recovery Training }\end{array}$ & - Rehabilitative treatment, Training for recovering function & & & & & & & & & & & \\
\hline $\begin{array}{l}\text { 介介護〉 } \\
\text { Health Care } \\
\end{array}$ & $\begin{array}{l}\text { - Support meals, bath, elimination and other benefit } \\
\text { - Helping get out of bed, change of clothes, and other action }\end{array}$ & & & & & & & & & & & \\
\hline $\begin{array}{l}\text { 〈看護〉 } \\
\text { Nursing Care }\end{array}$ & - Long-term care under medical management & & & & & & & & & & & \\
\hline $\begin{array}{l}\text { 医療〉 } \\
\text { Medical Care }\end{array}$ & - Medical examination & & & & & & & & & & & \\
\hline
\end{tabular}




\section{2-2. 長期居住者を対象とした訪問サービス等による在宅福祉}

簡易宿泊所内における在宅福祉の実態を明らかにするため、宿泊 室への訪問を行なう各施設の支援内容と一般的な福祎施設での福祉 サービスを比較し考察する。福祉機能の項目は養介護施設、保護施 設、高齢者住宅における設備及び運営基準に関する厚生労働省令や 根拠法 ${ }^{7}$ から運営基準やサービス内容に関する記述を抜粋し、〈宿 所の提供〉、〈作業指導〉、〈自立支援〉、〈趣味活動の場〉、〈食事の提 供〉、〈入浴機会の提供〉、〈生活支援〉、〈健康管理〉、〈機能訓練〉、〈介 護〉、〈看護〉、〈医療〉を抽出した（Table3）。

長期居住者の高齢化に伴い、簡易宿泊所外から宿泊室を訪問して 福祉サービスを提供する事例が存在する。地区内の日雇労働を管理 する労働福祉センターでは、職員が簡易宿泊所を週 2 回程度巡回し、 生活相談・健康相談を実施している。地区内の路上生活者を支援す る NP0 法人はボランティアを派遣し、見守り訪問、日常生活支援を 行なっている。また、各地区に存在する訪問看護ステーションでは、 簡易宿泊所の各宿泊室を対象として家事援助、血圧測定・血糖測定・ 結核検診への促し等の訪問介護・訪問看護を提供している。

これらの福祉サービスは、一般的な福祉施設では〈生活支援〉、〈健 康管理〉、〈介護〉、〈看護〉等の福祉機能として提供されるものであ り、簡易宿泊所は宿泊施設でありながら多数の高齢の居住者が長期 生活し、サービス付き高齢者向け住宅とほぼ同様のサービスを享受 している居住者も存在する。宿泊施設の範疇を超えた長期生活の場 となっている中で、老人ホーム等に入居可能な要介護者が簡易宿泊 所内への訪問サービスにより福祉機能の多くを享受している等、簡 易宿泊所が「終の棲家化」している実態を把握した。

\section{1989 年以降における福祉機能の経年変化}

日雇労働者が利用していた機能の福祉転用実態を明らかにする ため、日雇労働求人数がピークとなる 1989 年以降における住宅地 図分析を行ない、機能の経年変化を考察する。2016 年現在、地区 内に事務所や店舗をもつ企業や団体総数のうち、寿地区では $15 \%$ 、 山谷地区では $10 \%$ が福祉施設であり、これを対象に施設経年変化 と居住者の 60 歳以上人口割合・生活保護受給率との比較・分析を 行なった（Table4）。

\section{3-1. 1989 年以降における施設変遷}

寿地区における全福祉施設 55 件の 1989 年以降における経年変化 をFig. 3 に示す。訪問介護ステーションやデイサービスセンター 等の介護施設は、地区居住者の $50 \%$ 以上が 60 歳以上となった 2006 年の前後から開設され、60 歳以上人口割合が $65 \%$ 前後となった最 近 5 年間で急増している。訪問介護ステーションの増加から在宅介 護需要の高まりがうかがえる。また、簡易宿泊所は食堂等の共用空 間が存在せず、建物内でリハビリテーションを行なうことができな いため、〈機能訓練〉を行なうデイサービスセンターが増加してき たと考えられる。一方、生活相談室や福祉作業所等、居住者への生 活支援等を行なう施設は、介護需要が高まる 2006 年以前から存在 している。これは、身寄りのない居住者にとって生活相談や自立支

Table 4 The number of facilities in 2016

\begin{tabular}{|c|c|c|c|c|c|c|}
\hline & \multirow{2}{*}{ buildings } & \multirow{2}{*}{ flophouses } & \multirow{2}{*}{\begin{tabular}{|l|} 
- empty \\
- rental house
\end{tabular}} & \multirow{2}{*}{ houses } & \multirow{2}{*}{\multicolumn{2}{|c|}{$\frac{\text { spaces for facility }}{\text { welff }}$}} \\
\hline & & & & & & \\
\hline $\begin{array}{l}\text { Kotobuki area } \\
\text { (Yokohama) }\end{array}$ & 241 & 124 & $1002(64.4 \%)$ & $196(12.6 \%)$ & $358(23.0 \%)$ & \\
\hline $\begin{array}{l}\text { Sanya area } \\
\text { (Tokyo) }\end{array}$ & 2862 & 137 & 2311 (38.7\%) & $2697(45.2 \%)$ & $964(16.1 \%)$ & \\
\hline
\end{tabular}

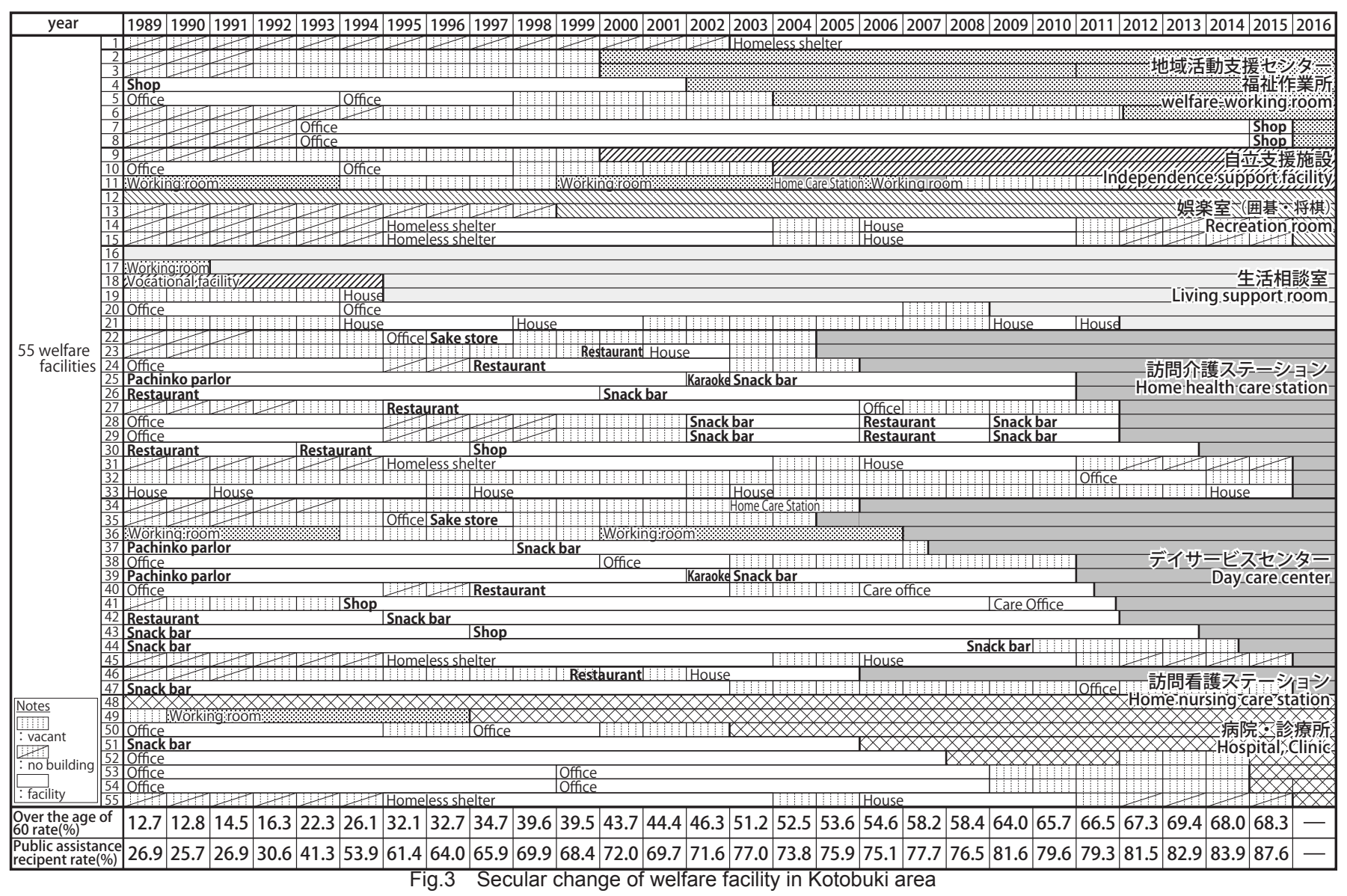


援等は年齢や時期に関わらず必要であったことが要因である。

施設変化をみると、事務所や住戸が生活相談室や福祉作業所等の 施設に転用している一方で、パチンコ屋や居酒屋等の遊技施設や飲 食店の多くが介護施設に転用していることが確認できた

次に、山谷地区における全福祉施設 94 件の 1989 年以降における 経年変化をFig. 4 に示す。寿地区と同様に、訪問介護ステーション やデイサービスセンター等の介護施設は、居住者の過半数が 60 歳 以上となった 1999 から 2000 年の前後に地区に開設され、年々増加 している。生活相談室や福祉作業所等、居住者への生活支援や自立 支援をおこなう施設は、寿地区と同様に福祉需要が高まり介護施設
が地区内に増加し始めた以前から地区に存在している。

また、山谷地区は寿地区と比較して、特別養護老人ホームやグルー プホーム等、高齢者が入居する福祉施設が多く立地していることが 特徵である。特に、生活支援をおこなう福祉アパートが多く存在す るが、それらの中には簡易宿泊所からの建替え事例がみられる。低 層階の宿泊室の一部を共同リビングやスタッフルーム等に改修し、 服薬管理等による〈生活支援〉や、健康診断による〈健康管理〉の 他、共同リビングの設置により〈趣味活動の場〉、〈機能訓練〉等の 機能を新たに付加させている。簡易宿泊所という運営体系から、入 居系介護施設へと転用することで、低所得高齢者が享受できる機能

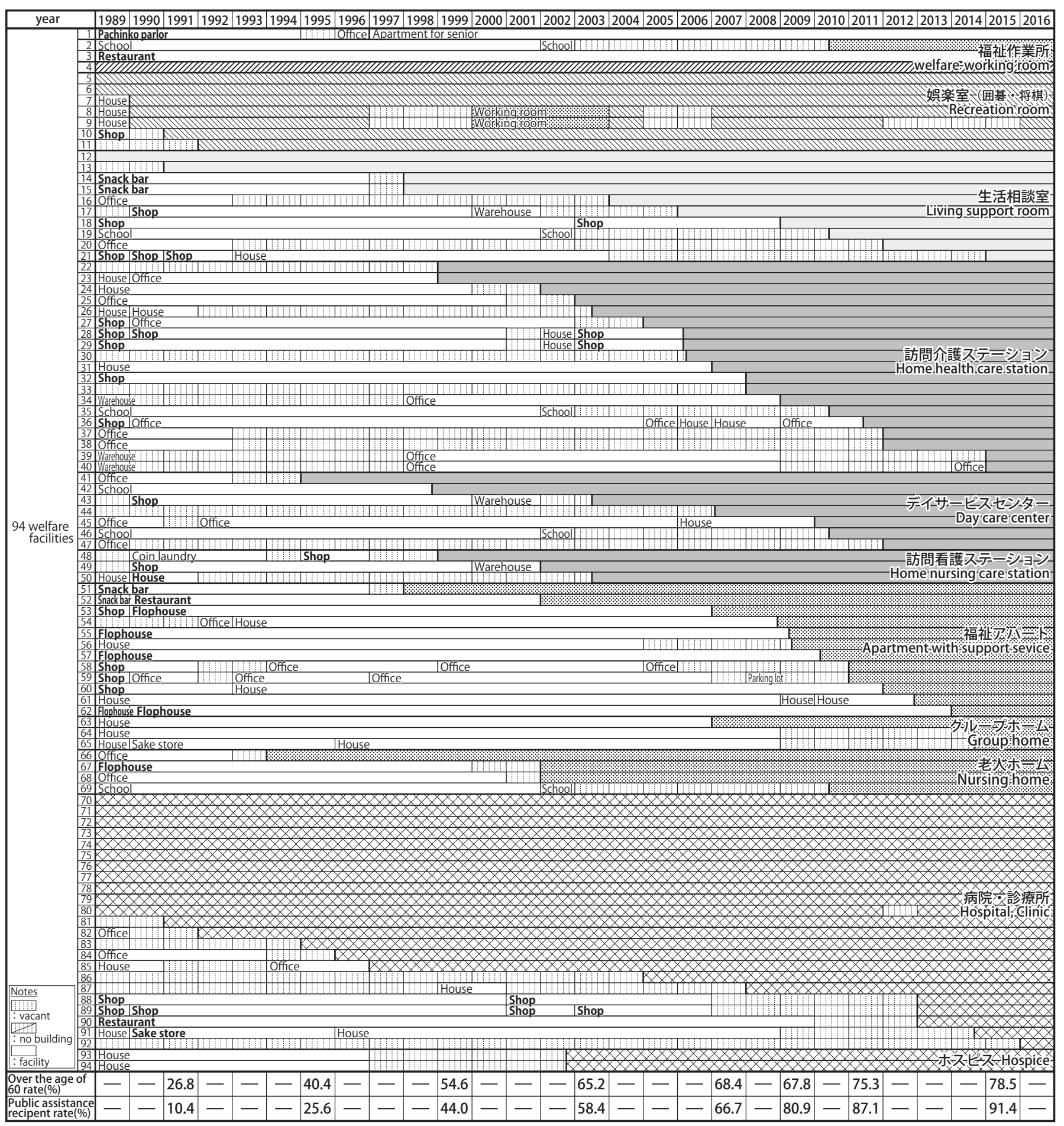

Fig.4 Secular change of welfare facility in Sanya area 
が地区内に増加し、福祉需要に対応している一面がみられる。

\section{3-2. 福祉機能の転用実態}

施設転用を機能の経年変化で整理するため、2 章で設定した福祉 機能を〈A-1：要介護者等、長期居住者が主に利用する福祉機能〉、 $\langle\mathrm{A}-2$ : 日雇労働者や生活困窮者等が主に利用する福祉機能〉に分類 する。また、パチンコ屋等の〈遊技〉注 2)、居酒屋等の〈飲食〉薬 局や酒屋等の〈販売〉、オフィス等の〈事務〉住宅等の〈居住〉、ホ テル等の〈宿泊〉を新たに設定し、〈B：旅行者等、健康な宿泊者が 主に利用する機能〉、〈C : その他の機能〉に分け、地区内の機能を $\langle\mathrm{A}-1\rangle 、\langle\mathrm{~A}-2\rangle$ 、 $\langle\mathrm{B}\rangle 、\langle\mathrm{C}\rangle$ の 4 つに分類し分析の指標とした（Table5）。

福祉機能の立地状況と機能変化をFig. 5 に示す。寿地区では、 2016 年時点で〈 $\mathrm{A}-2$ : 日雇労働者や生活困窮者等が主に利用する福 祉機能〉をもつ施設が 18 件存在するが、そのうち 14 件は〈C: 事務、 居住等の機能〉から転用している。また、〈A-1：要介護者等、長期 居住者が主に利用する福祉機能〉をもつ施設は 18 件存在するが、 そのうち 15 件は $\langle\mathrm{B}$ ：遊技・飲食等、健康な宿泊者が主に利用する 機能〉から転用している。〈居住〉、〈事務〉等の〈C〉の機能が主に 〈作業指導〉や〈生活支援〉等、〈A-2〉の機能に転用している一方で、 〈遊技〉、〈飲食〉等〈B〉の機能の約 9 割が〈介護〉、〈機能訓練〉等 $\langle A-1$ : 要介護者等、長期居住者が主に利用寸る福 祉機能〉に転用していることを明らかにした。

山谷地区では 2016 年時点で存在する $\langle A-1\rangle$ の 機能をもつ施設 17 件のうち、8 件が〈B〉の機能 をもつ施設から転用している。また、簡易宿泊所 から入居系施設への転用により、本来は居住者の みならず宿泊者が利用可能な〈B:宿泊〉が減少し、 $\langle\mathrm{A}-1$ : 介護等 $\rangle$ や $\langle\mathrm{A}-2$ : 健康管理等 $\rangle$ 、生活困窮 者や長期居住者のための機能が地区内に増加して いる。
以上から、旅行者等、健康な宿泊者が主に利用する〈B〉の機能 が軒並夕福祉転用し、〈介護〉等、「利用者層が要介護者や長期居住 者に限られる〈A-1〉の福祉機能」が地区内に密集して整備されて いる実態を明らかにした。

\section{4. 長期居住者の生活空間課題と支援の方向性}

\section{4-1. 長期居住者の生活空間としての簡易宿泊所における課題}

簡易宿泊所の運営体系のまま高齢の居住者が長期居住することの 課題を考察するため、簡易宿泊所に宿泊して行なった実測調査と、 簡易宿泊所管理者へのヒアリング調査を行なった。

長期居住者が生活する山谷地区の木造簡易宿泊所の内部空間を Fig. 6 に示す。宿泊室は $900 \mathrm{~mm} \times 1200 \mathrm{~mm}$ の畳 3 畳分の大きさで、幅 は廊下と同程度である。簡易宿泊所内には高齢者住宅や老人ホーム 等とほぼ同様のサービスを享受している居住者も存在するものの、 玄関や出入口に段差があり和式トイレがほとんどである等、バリア フリー面に課題が残る。また、狭い廊下に電子レンジ等の生活設備 が置かれ、空間に物理的な余裕がなく高齢の居住者や要介護者の生 活が不自由な空間である。居住者の介護需要がさらに高まった場合 には、介護施設への転居、もしくは簡易宿泊所の高齢者住宅等への

Table $5 \quad 4$ types of function

\begin{tabular}{|c|c|c|c|c|c|c|c|}
\hline & 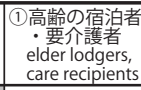 & $\begin{array}{r}\text { (2) 日雇労働者 } \\
\text { a-day-laborer } \\
\text { a-day peedy people } \\
\text { need }\end{array}$ & $\begin{array}{l}\text { 3) 旅行者等 } \\
\text { 健廉泊者 } \\
\text { healthy people, } \\
\text { tourists } \\
\end{array}$ & \multicolumn{4}{|c|}{ function } \\
\hline A-1 & $\begin{array}{l}\text { 主に利用する } \\
\text { People use them } \\
\text { mainly }\end{array}$ & $\begin{array}{l}\text { 利用されない } \\
\text { They are not used }\end{array}$ & $\begin{array}{l}\text { 利用されない } \\
\text { They are not used }\end{array}$ & \begin{tabular}{|l}
$\langle$ 入浴機会の提供〉 \\
Oppotunity to Bathe
\end{tabular} & $\begin{array}{c}\langle\text { 機能訓練〉 } \\
\text { Recovery Training }\end{array}$ & $\begin{array}{c}\text { 〈介護〉 } \\
\text { Health Care }\end{array}$ & $\begin{array}{l}\langle\text { 看護〉 } \\
\text { Nursing Care }\end{array}$ \\
\hline A-2 & $\begin{array}{l}\text { 主に利用する } \\
\text { People use them } \\
\text { mainly }\end{array}$ & $\begin{array}{l}\text { 主に利用する } \\
\text { People use them } \\
\text { mainly }\end{array}$ & $\begin{array}{l}\text { 利用されない } \\
\text { They are not used }\end{array}$ & $\begin{array}{c}\text { 〈宿所の提供〉 } \\
\text { Providing Accommodation } \\
\text { 〈食事の提供〉 } \\
\text { Food Supply }\end{array}$ & $\begin{array}{c}\text { 〈作業指䆃〉 } \\
\text { nook Instruction } \\
\langle\text { 生活支援〉 } \\
\text { Living Support }\end{array}$ & $\begin{array}{c}\text { 〈自立支援〉 } \\
\text { n Independence Support } \\
\quad\langle\text { 健康管理〉 } \\
\text { Health }\end{array}$ & $\begin{array}{c}\text { 趣味活動の場〉 } \\
\text { Place for Activity } \\
\text { 〈医療〉 } \\
\text { Medical Care }\end{array}$ \\
\hline $\mathrm{B}$ & $\begin{array}{l}\text { 健康な宿泊者は } \\
\text { 者 } \\
\text { Healthy people } \\
\text { can use them }\end{array}$ & 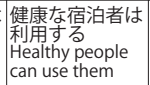 & $\begin{array}{l}\text { 主に利用する } \\
\text { People use them } \\
\text { mainly }\end{array}$ & $\begin{array}{l}\langle\text { 〈斿技〉 } \\
\text { Game }\end{array}$ & $\begin{array}{l}\text { 〈飲食〉 } \\
\text { Eating }\end{array}$ & $\begin{array}{c}\langle\text { 販売〉 } \\
\text { Commerce }\end{array}$ & $\begin{array}{l}\text { 〈宿泊〉 } \\
\text { Lodging }\end{array}$ \\
\hline C & $\begin{array}{l}\text { 利用されない } \\
\text { They are not used }\end{array}$ & \begin{tabular}{|l|} 
利用されない \\
They are not used
\end{tabular} & $\begin{array}{l}\text { 利用されない } \\
\text { They are not used }\end{array}$ & $\begin{array}{c}\langle\text { 事務〉 } \\
\text { Business }\end{array}$ & $\begin{array}{c}\langle\text { 居住〉 } \\
\text { Residing }\end{array}$ & & \\
\hline
\end{tabular}

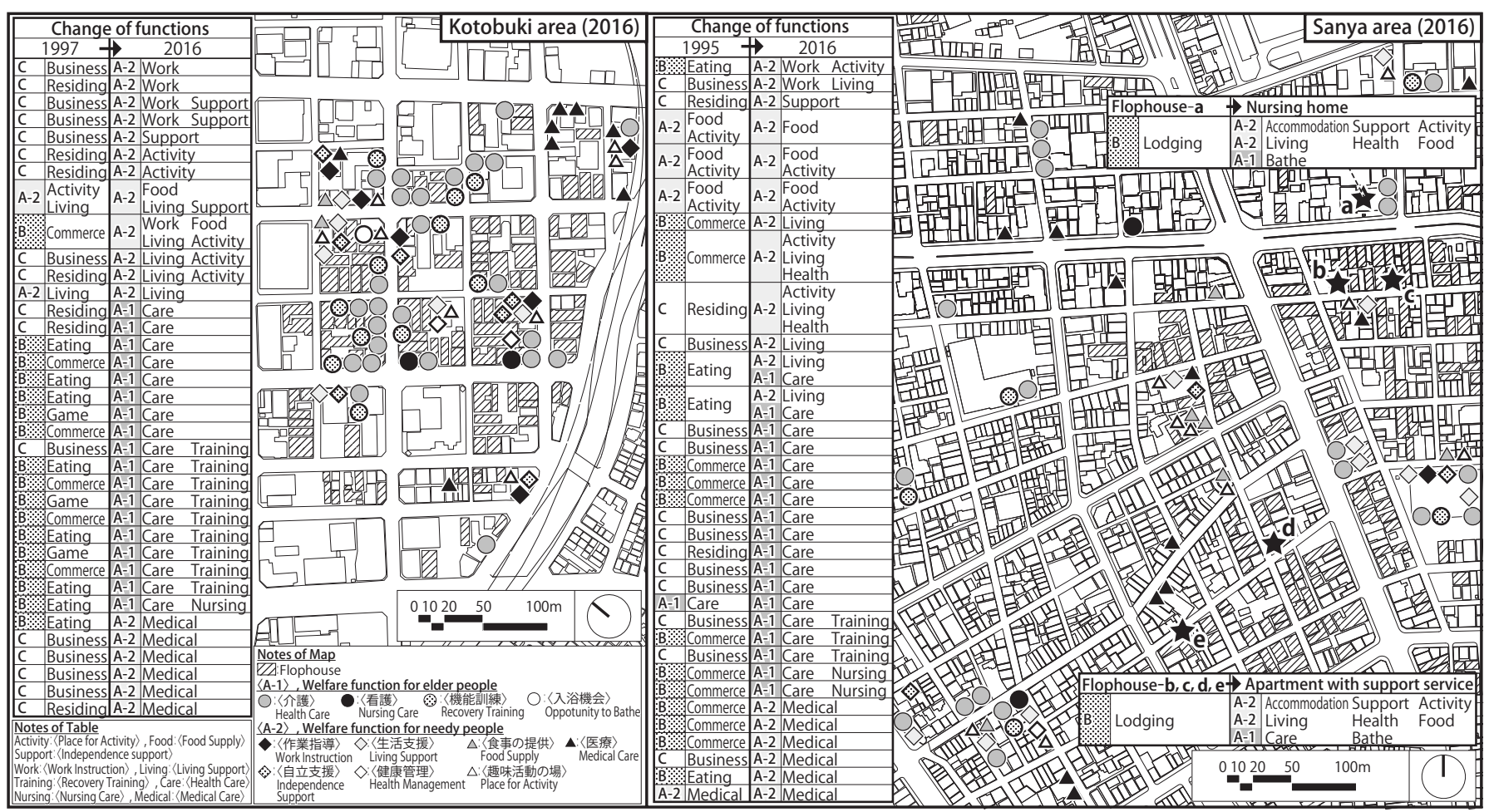

Fig. 5 Location and change of welfare functions 
大規模改修や建替えが必要となるため、山谷地区では訪問介護ス テーションやデイサービスセンター等の福祉施設に加え、要介護者 が入居する福祉アパート等が増加しており、在宅サービスの提供と 入居系介護施設の増加により簡易宿泊所の機能を補完している。

車椅子使用者の宿泊を受け入れている寿地区の簡易宿泊所の内部 空間をFig. 7 に示す。高齢の居住者用の宿泊室を低層階に配置し、 出入口にスロープを設けて車椅子対応をおこなう等、最低限のバリ アフリー対応を行なう一方、入浴設備はコインシャワーのみであ り、食堂等の共用空間が存在しないため、〈趣味活動の場〉、〈機能 訓練〉等の福祉機能を建物内で享受できない等、車椅子使用者や杖 歩行の高齢者の生活は困難であるという課題が存在する。一方で、 地区内には訪問介護ステーションやデイサービスセンター等在宅 サービスを提供する福祎施設が増加しており、通所介護による訪問 入浴やレクリエーションを利用することで、簡易宿泊所で享受でき ない機能を補完している。

以上から、両地区の建築形態の違いにより福祉需要が高まった場 合のサービス提供の方向性が異なるが、簡易宿泊所の機能を地区内 で福祉転用した施設が補完することで、バリアフリー整備の限界や 簡易宿泊所を住居とみな寸政策限界等の課題を抱えつつも、多くの 高齢居住者が簡易宿泊所内に長期生活寸る状況であることを明らか にした。

\section{4-2. 長期居住者支援の方向性の課題}

長期居住者支援の方向性の課題を考察するため、各自治体福祉部 局、長期居住者支援組織を対象としたヒアリング調查を行なった。

高齢になるにつれ、地区を出て自立生活を送ることを希望する居 住者は減少する傾向があり注3)、簡易宿泊所を住居とした在宅介護 を希望する事例が多くなるが、現在居住者の約 7 割が 60 歳以上で あることから、10～20 年後に居住者の多くが亡くなる等を想定す ると、近年増加してきた福祉機能の地区内ニーズが今後減少する可 能性が考えられるため、現時点での福祉機能転用傾向が将来的に継 続するのかどうかを注意してみていく必要がある。

山谷地区の訪問看護ステーションは、2000 年に訪問看護・居宅 介護支援の事業所認可を受け地区に開設され、現在は地区周辺の住 宅や福祉アパートの他、簡易宿泊所の宿泊室を対象とした訪問介 護・看護を主な業務としており、健康相談では簡易宿泊所を 1 軒ず つ巡回して居住者の健康管理をおこなっている。開設当初は地区内 の簡易宿泊所を対象とした訪問看護が、1 日あたり $40 \sim 50$ 軒ほど の業務先のほとんどを占めていた。一方で現在では、簡易宿泊所内 で福祉サービスを受ける高齢者層はピークを過ぎ減少し始めてお り、地区外への訪問看護が増加している状況にある、という回答が

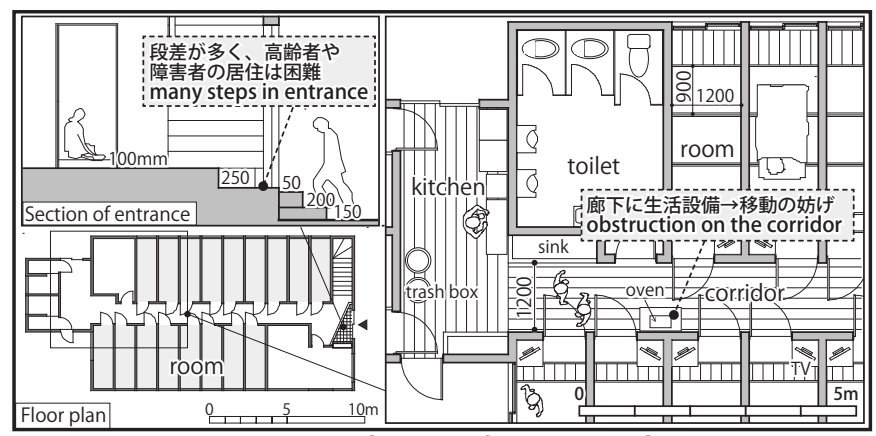

Fig. 6 Inner space of general flophouse in Sanya area
ヒアリング調査から得られた。地区内の機能が軒並み福祉転用寸る ことで福祉機能が密集して整備され、低所得の高齢居住者のみが長 期的に生活する現在の様相とは異なり、地区内の福祉機能が縮小し 始めている一面もみられる。

\section{5. 結論}

本研究は、簡易宿泊所密集地区における福祉機能転用に関して、 下記の結論を得た。

2 章、宿泊者層に関する文献調査では、現在は地区での日雇労働 求人数が大きく減少し、宿泊者の大半が 60 歳以上で、生活保護を 受給しながら長期居住していることを確認した。また、簡易宿泊所 の機能分析では、宿泊室への訪問福祉サービスにより、簡易宿泊所 が宿泊施設でありながら、宿泊室を住居とした福祉活動が展開さ れ、高齢者住宅等とほぼ同様のサービスを享受している居住者も存 在する実態を明らかにした。

3 章、1989 年以降における福祉機能の経年分析では、旅行者等、 健康な宿泊者が主に利用する〈B〉の機能が福禅転用し、「利用者層 が要介護者や長期居住者に限られる〈A-1〉 の福祉機能」が地区内 に密集して整備されていることを確認し、福祉機能の地区内ニーズ が近年急増してきたことを明らかにした。

4 章、簡易宿泊所の宿泊による空間実測調查では、玄関や出入口 に段差があり、入浴設備がコインシャワーのみである等バリアフ リー整備に限界があることを確認した。また、両地区の建築形態の 違いが、転用寸る福祉施設の種類や提供されるサービス内容に影響 している一面を捉えた。福祉施設運営者を対象としたヒアリング調 查では、機能転用により福祉施設が増加してきた一方で高龃者層の 将来的な減少も推測されていることを確認し、居住者支援の方向性 についての課題を捉えた。

今後高齢の長期居住者増のピークが過ぎて減少した場合、将来的 には、（I）簡易宿泊所や福祉アパートの空室化、（II）外部からの 失業者等が地区に流入することによる新規居住者層の増加、（III） 外国人バックパッカー等の旅行者の増加注 4 、をを想定することがて きる。（Ｉ）高齢の居住者層が減少した場合は、増加してきた福祉 施設が空き家になる、もしくは商業的な機能に再び戻ることとな る。（II）流入者が増加する場合、低所得高齢者が次々に地区外か ら流入することで、地区居住者の年齢層は現在と変わらないことが 考えられる。現在地区に存在する福祉機能の需要が高いまま、高齢 の生活困窮者の居住地の様相であり続ける。（III）旅行者が増加す る場合は、簡易宿泊所は安宿運営への変化が求められ、地区内には 旅行者が利用する〈飲食〉等の〈B〉に含まれる機能が増加するこ

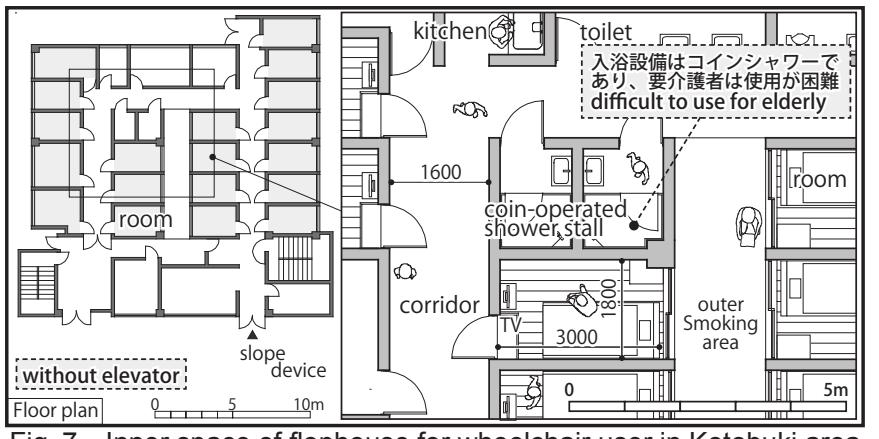

Fig. 7 Inner space of flophouse for wheelchair user in Kotobuki area 


\section{とことが想定される。}

機能転用により簡易宿泊所密集地区が高齢の生活困窮者の居住地 の様相となっている一方で、（Ｉ）（II）（III）のバランスにより、 今後の地区の様相と居住者支援の方向性は変化していくことが想定 され、今後も街区の変化を慎重にみていく必要がある。

\section{謝辞}

ヒアリング調查にご協力頂いた自治体福祉部局、及び特定非営利 活動法人の皆様に御礼申し上げます。また、宿泊による現地調査を 受け入れて下さった簡易宿泊所管理者の皆様に感謝申し上げます。

注

注 1）日雇労働を斡旋する寄せ場は全国の大都市圈に存在しているが、文献 1）より、全国の寄せ場における日雇い労働者の概数が他の地区と比べて極 めて多い寿地区（横浜市）、山谷地区（台東区・荒川区）、あいり几地区（大 阪市）は一般に日本三大寄せ場と称されている。一方で大阪市は簡易宿泊 所を住居として住民票を取得し、居宅保護を受給することを認めていない ため、簡易宿泊所に居住しながら訪問介護を受給することが可能な寿地区・ 山谷地区と様相が異なるため、本研究では日本三大寄せ場からあいりん地 区を除いた 2 地区を調查対象地としている。

注 2）マージャン店、パチンコ屋、ゲームセンター等「風俗営業等の規制及 び業務の適正化等に関する法律」の対象となる、許可が必要な遊技場の機 能を〈遊技〉とした。

注 3）文献 6）より、簡易宿泊所宿泊者のうち、60 歳以上の宿泊者の $64 \%$ 、 70 歳以上の宿泊者の $81 \%$ が、今後の生活について「このまま生活保護を受 給しながら簡易宿泊所」を希望しており、高齢になるにつれて地区外での 自立生活を希望する居住者は隇少寸る傾向にある。

注 4） 1989 年から 2016 年において、簡易宿泊所を利用する外国人バックパッ カー等の旅行者を取り上げた新聞記事数は 2002 年以降に急増しており、 2002 年の日韓W杯を契機に簡易宿泊所が安宿街として認識されるように なったと考えられる。対象とした新聞は朝日新聞・産経新聞・中日新聞・ 東京新聞・日経新聞・毎日新聞・読売新聞とした。

\section{参考文献}

1) Employment of Bureau of the Ministry of Labour : the yearbook of measure against unemployment, 1990

労働省職業局：失業対策年鑑，1990

2) Japan Association for the Study of Yoseba : A Bibliography of 306 Writings on Yoseba - The Underclass in Modern Japanese Society, 2004. 5

日本寄せ場学会：寄せ場文献精読 306 選一近代日本の下層社会一; 2004. 5

3) Reference announced by Health and Social Welfare Bureau of Yokohama City, 2016.3

横浜市健康福祉局生活福祉部保護課寿地区担当: 平成 28 年度寿福祉プ ラザ相談室一業務の概要—，2016.3

4) Reference announced by Johoku Labor and Welfare Center, 2016 公益財団法人城北労働・福祉センター：平成 28 年度公益財団法人城北 労働・福祉センター事業案内, 2016

5) Reference announced by Urban Research Plaza, Osaka City University, 2011.5 大阪市立大学都市研究プラザ : 大阪府 簡易宿所生活衛生同業組合 50 年 誌, 2011.5

6) Reference announced by Bureau of Social Welfare and Public Health of Tokyo, 2016.3

東京都福祉保健局生活福祉部生活支援課：山谷地域 一宿泊者とその生 活一，2016.3
7) the Ministry of Health, Labour, and Welfare : the standards of facilities and management of In-Home Service Business, Care Facility for Elderly, Intensive Care Home for Elderly, moderate-fee home for elderly, Community-Based Service, Long-Term Care Health Facility, Relief facility, Rehabilitation facility, Vocational facility, Facility providing accommodation, amended on 2016, 2 厚生労㗢省: 指定居宅サービス等、養護老人ホーム、特別養護老人ホーム、 軽費老人ホーム、指定地域密着型サービス、介護老人保健施設、救護施設、 更生施設、授産施設及び宿所提供施設の事業の人員、設備及び運営に関 寸る基準, 2016.2 改正

8) ZENRIN CO. , LTD. : ZENRIN residential maps of Naka-ku, Yokohama City, and Taito-ku, Arakawa-ku, Tokyo, 1989-2016 株式会社ゼンリン：ゼンリン住宅地図 横浜市中区、東京都台東区・荒 川区 ; 2016-1989

9) Kahoruko YAMAMOTO : Changes and Restructuring of Social Issues of the Urban Underclass Area with Increasing Welfare Needs in Kotobuki, Yokohama, The annals of Japan Association for Urban Sociology, pp95-110, 2013 山本薰子：現代日本の都市下層地域における福祉ニーズ増大と地域課 題の再編一横浜・寿町の事例から一，日本都市社会学会年報 pp95-110, 2013

10) Junko Nakamichi and Tomohiko Yoshida : Conditions of apartment house in Sanya, Summaries of Technical Papers of Annual Meeting, Architectural Institute of Japan, Urban Planning-1, pp1113-1114, 2006. 9

中道純子、吉田友彦 : 山谷地域におけるアパートの居住実態; 日本建築 学会大会学術講演梗概集, F-1, pp1113-1114 2006-9

11) Shigeki Kudo, Yasushi Takeuchi, Keita Aizawa and Taisei Chiba : The Study on Gradual Changes of Kotobuki Town, Yokohama City - The Consideration on the Facilities with the Living Function of The Urban Space in Japan No.1, Summaries of Technical Papers of Annual Meeting, Architectural Institute of Japan, Urban Planning, pp419-420, 2014. 9

工藤茂樹、竹内泰、相澤啓太、千葉大生 : 横浜寿町地区の変容過程一日 本の都市空間における住機能を備えた諸施設に関する研究 その 1 -

日本建築学会大会学術講演梗概集, 都市計画, pp419-420 2014-9

12) Keita Aizawa, Yasushi Takeuchi, Shigeki Kudo and Taisei Chiba : The Study on Actual conditions of the Dwelling - The Consideration on the Facilities with the Living Function of The Urban Space in Japan No.2, Summaries of Technical Papers of Annual Meeting, Architectural Institute of Japan, Urban Planning, pp421-422, 2014. 9

相澤啓太、竹内泰、工藤茂樹、千葉大生 : 横浜寿町地区の居住実態一日 本の都市空間における住機能を備えた諸施設に関する研究 その 2 ; 日本建築学会大会学術講演梗概集, 都市計画, pp421-422 2014-9

13) Mari Okazaki, Shuji Funo and Shu Yamane : Consideration on transformation of flophouses in Airin area (Kamagasaki), Nishinari-ku, Osaka City, Summaries of Technical Papers of Annual Meeting, Architectural Institute of Japan, pp135-136, 2008.9

岡崎まり、布野修司、山根周：大阪市西成区あいりん地域 ( 釜ヶ崎) に おける簡易宿泊所の変容に関する考察; 日本建築学会大会学術講演梗概 集 pp135-136 2008-9

14) Mari Okazaki, Shuji Funo, Shu Yamane and Naohiko Yamamoto : Consideration on formation process of "supportive house" and its spatial pattern in Airin area (Kamagasaki), Nishinari-ku, Osaka City, Summaries of Technical Papers of Annual Meeting, Architectural Institute of Japan, pp239-240, 2007.8 岡崎まり、布野修司、山根周、山本直彦: 大阪市西成区あいりん地域（釜ヶ 崎）におけるサポーティブハウスの成立過程とその現状に関する考察； 日本建築学会大会学術講演梗概集 pp239-240 2007-8

15) Kazuaki Nakamura, Shunsuke Yokoyama and Tetsu Tokuono : Study on living condition and communication of the apartment converted from flophouses, Summaries of Technical Papers of Annual Meeting, Architectural Institute of Japan, Architectural Planning-II, pp351-352, 2011. 8 中村和晶、横山俊祐、徳尾野徹 : 簡易宿泊所転用型アパートにお注る生 
活実態と交流に関する研究; 日本建築学会大会学術講演梗概集, 建築計

画 II, pp351-352 2011-8

16) Tetsuo Tominaga : A study on the actual condition of flophouses and diversion house In Airin area (Kamagasaki), Nishinari-ku, Osaka City, Summaries of Technical Papers of Annual Meeting, Architectural Institute of Japan, Architectural Planning, pp1471-1472, 2013.8

冨永哲雄 : 大阪市西成区あいりん地域 (釜ヶ崎) における簡易宿所およ び転用共同住宅の実態に関する研究; 日本建築学会大会学術講演梗概集, 建築計画, pp1471-1472 2013-8

17) Masaki Nakai, Takao Morita, Koichi Sakata and Masato Takagi : Researching the type and the characteristics of the choice of the residence facilities in Airin district, Osaka, AIJ Kinki Chapter research meeting, pp45-48, 2006. 5

中井真樹、森田孝夫、阪田弘一、高木真人 : 大阪あいりん地区における 居住施設の類型と居住者の施設選択特性一大阪あいりん地区における居 住施設改善に関寸る研究 その 1 - ; 日本建築学会近畿支部研究報告集 pp45-48 2006-5

18) Katsushi Horikawa, Takao Morita, Koichi Sakata and Masato Takagi : A study on the planning and problem of supportive houses in Airin district, Osaka, AIJ Kinki Chapter research meeting, pp49-52, 2006.5

堀川勝史、森田孝夫、阪田弘一、高木真人 : 大阪あいりん地区における サポーティブ八ウスの計画実態と課題一大阪あいりん地区における居 住施設計画に関寸る研究 その 2 - 日本建築学会近畿支部研究報告集 pp49-52 2006-5

19) Katsushi Horikawa, Takao Morita, Koichi Sakata and Masato Takagi : The actual condition of residents' living activities in the residence which support the resident in flophouse quarters, AIJ Kinki Chapter research meeting, pp785-788, 2007

堀川勝史、森田孝夫、阪田弘一、高木真人：寄せ場型地域における自立 支援機能を有する共同住宅の居住実態; 日本建築学会近畿支部研究報告 集 pp785-788 2007

20) Akiko Nakajima, Michiko Bando, Hajime Osaki and Magokoro Yoshihira : Possibility of regeneration and housing support for homeless people in flophouse quarters - Part.1 Outline of the research and human resources, Summaries of Technical Papers of Annual Meeting, Architectural Institute of Japan, Urban Planning-1, pp1135-1136, 2002. 8

中島明子、阪東美智子、大崎元、義平真心 : 寄せ場型地域における地域 再生とホームレスの人々への居住支援の可能性一その 1 研究の枠組み と人的地域資源一; 日本建築学会大会学術講演梗概集, F-1, pp1135-1136 $2002-8$

21) Hajime Osaki, Akiko Nakajima, Michiko Bando and Magokoro Yoshihira : Possibility of regeneration and housing support for homeless people in flophouse quarters - Part.2 Comparison between Sanya and Kamagasaki, Summaries of Technical Papers of Annual Meeting, Architectural Institute of Japan, Urban Planning-1, pp1137-1138, 2002.8

大崎元、中島明子、阪東美智子、義平真心 : 寄せ場型地域における地 域再生とホームレスの人々への居住支援の可能性一その 2 山谷・釜ヶ 崎の地域比較一; 日本建築学会大会学術講演梗概集, F-1, pp1137-1138 2002-8

22) Michiko Bando, Akiko Nakajima, Hajime Osaki and Magokoro Yoshihira : Possibility of regeneration and housing support for homeless people in flophouse quarters - Part. 3 Use Change of flophouses in Kamagasaki, Summaries of Technical Papers of Annual Meeting, Architectural Institute of Japan, Urban Planning-1, pp1139-1140, 2002. 8

阪東美智子、中島明子、大崎元、義平真心 : 寄せ場型地域に抢ける地 域再生とホームレスの人々への居住支援の可能性一その 3 釜ヶ崎に おける簡易宿泊所の経営動向一; 日本建築学会大会学術講演梗概集, F1, pp1139-1140 2002-8 


\title{
THE CURRENT STATUS AND PROBLEMS OF CONVERSION INTO WELFARE FACILITY IN FLOPHOUSE AREAS
}

\author{
Kazuhiko ONO* and Naoko SAIO** \\ * Ministry of Land, Infrastructure, Transport, and Tourism, M.Eng. \\ ** Assoc. Prof., Dept. of Arcitecture and Building Engineering, School of Environment and Society, Tokyo Institute of Technology, Dr.Eng.
}

Flophouse areas were formed by establishing many snack bars, cheap restaurants, amusement facilities such as pachinko parlors, and flophouses densely around employment agency for day laborers. At general flophouse, floor size of guestroom is 3 tatami mats, it does not have common space such as restaurant and lobby lounge, bathing equipment is coin־operated shower stall, and the charge is around 1500 yen. The areas were once the base for day laborers. Recently, due to aging of long-term residents who had been day-laborer, some of residents get home-visit care nursing services and medical checkup services in each room of flophouse, and some of pachinko parlors and snack bars converted into welfare facilities such as day care center for lowincome elderly people.

On the other hand, we need to discuss the rights and wrongs of being welfare areas for only single person with very lowincome and the elderly, and increasing converted welfare facilities in case of replacement of residents in the future.

This research aims to explore the current status and problems involved in conversion into welfare facilities from facilities for day-laborer in main flophouse areas in metropolitan area of Japan (Kotobuki area in Yokohama City, Sanya area in Taito-ku and Arakawa-ku, Tokyo). We describe the secular changes of welfare function by researching residential maps in the areas for 28 years between 1989 and 2016, and we describe problem of direction about support for long-term residents in the areas by field survey. In this research, we extracted services offered for people in the facilities as the facility function.

In Chapter 2, we examine the number of the offer of day labor at the employment agency, the aging rate, public assistance recipient rate, and the years of residing by researching references announced by each local government, labor and welfare center. In addition, we also describe the current status that elderly people can reside in the long term, due to addition of welfare function to flophouse by visiting welfare services for residents in flophouse. In this process, we analyze the change of function by comparison the welfare services in flophouse and in ordinary welfare facility.

In Chapter 3, we clarify the converting condition into welfare functions from functions for young people and day-laborers. Specifically, we describe the secular changes of welfare facilities in the areas by researching residential maps from 1989 when the number of day-labor offers are the most in the last 40 years. In this analysis, we examine the secular change of existing welfare facilities in 2016.

In Chapter 4, we extract problems that flophouse continue to be place of residence in the long term for elderly people as lodging facility, by measuring inner space of flophouse and hearing survey to the manager of 4 flophouses in the areas. In addition, we also describe the assumption of residing group in flophouse, the change of function in the areas, and the problems involved in the direction of support for long-term residents in case the number of elderly residents decrease in the future by hearing survey to each local governments, support groups for residents, care offices.

(2017 年 3 月 29 日原稿受理, 2017 年 9 月 25 日採用決定） 